Indonesian Journal of EFL and Linguistics

Vol. 6 No. 1, 2021

eISSN: 2503-4197, pISSN: 2527-5070

www. indonesian-efl-journal.org

doi: http://dx.doi.org/10.21462/ijefl.v6i1.360

\title{
Subtitling Strategies of Swear Words in Deadpool One \& Deadpool Two Film
}

\author{
Rohmawati \\ Universitas Gunadarma, Jakarta, Indonesia \\ e-mail: rohmawati.sarmag2015@gmail.com
}

\begin{abstract}
:
Subtitles has always been seen as a savior by a lot of people because it breaks all language barriers and made various films and series to be more understandable and watchable. However, the act of subtitling is not as easy as other people think. There are so many restraints in subtitling. One of those restrains is cultural differences in translating swear words. This research aims to obtain data concerning the subtitling strategies of swear words that are found in the subtitles of Deadpool One and Deadpool Two films. The descriptive qualitative method is employed because this research relies on the data obtained from subtitles, which are non-numerical data, and the data analysis will be served descriptively. The results of this research show that according to Gottlieb's (1992) theory, the subtitlers for Deadpool One and Deadpool Two used six different subtitling strategies in each film. The subtitler in Deadpool One tends to use the paraphrase and deletion strategies, followed by condensation, decimation, and transfer, with expansion being the least employed. The subtitler in Deadpool Two, on the other hand, employs deletion as the most used strategy. The subtitler's next most used strategies are paraphrase, condensation, decimation, and transfer; the least commonly employed strategy is expansion.
\end{abstract}

Keywords: audiovisual translation, subtitle, subtitling strategies, swear words 


\section{Rohmawati}

\section{INTRODUCTION}

Over the last century, the film industry has made a lot of contributions in delivering the beauty of languages to the world through audiovisual translation (Cintas, 2005). Especially the American film Industry, a hegemon who produces various kinds of films. Due to the increasing number of interests in film businesses around the world, the research of audiovisual translation has gotten a lot of coverage (Kao, 2011). An increasing number of researches on subtitling, in particular, are now available to the general public. The setting for this research is Indonesia, where many people use the most popular type of audiovisual translation, which is subtitles. Most of the screen translation work in Indonesia is from English to Indonesian (Sari \& Zamzani, 2020).

According to Díaz Cintas and Remael (2014), "Subtitling is a method of translation that includes showing a written text, that normally appears on the lower half of the frame, that strives to recount the original dialogue of the speakers, and also discursive elements that occur in the picture (letters, inserts, graffiti, inscriptions, etc.), as well as details from the soundtrack (songs, voices off)." Based on the definition, it is safe to say that subtitling is not only consisted of translating film dialogue and narrative, but there is much more than that.

The process of subtitling is not easy. Ivarsson and Carroll as cited in (Hawel, 2019) explained that a script or a dialogue list in the source language is normally given to the subtitler. In the best-case situation, they receive a post-production script that covers the whole dialogue, even some sections that are difficult to hear. If they're fortunate, they will even get a glossary of explained dialect terms, slang words, swear words, local jokes, and so on. That being said, owing to the likelihood of inconsistencies and differences between the dialogue list and the original film dialogue, particular consideration should be given to the dialogue list. As a consequence, the subtitles would conform to what is currently being said.

Based on the statement above, it is clear that making subtitles is not an easy task to do. Especially, making subtitles for a film that has a lot of swear words. In Indonesian culture, swear words are considered taboo, and subtitlers cannot freely translate the source language swear words into Indonesian. Swearing may take the form of words or phrases that the majority of people deem to be blasphemous, indecent, vulgar, or sometimes insulting. "Swearing at someone or something is a form of provocation and deprecation, as well as the use of other dysphemisms." (Allan \& Burridge, 2006). Swear words, are used to insult, condemn, or speak offensively to other individuals or in unexpected circumstances (Amrullah, 2016).

Simultaneously, modern American films are watched all over the world, including by many people in Indonesia who do not speak English as their first language. When people who are not native in the English language watching film in its original form, it can be an effective way for students to encounter spoken English and can make it their object of learning English (Amri, 2017). This is particularly true in the case of 
swear words since this kind of taboo term is never considered to be included in the textbook or to be taught in school in Indonesia, since the people who swear are considered to be barbaric and violent, which is not following Indonesian culture custom. Also, many young people in Indonesia often use English swear words but have little understanding of how to use them. They just like to copy what they see and hear from films and television.

Using the original film version and its Indonesian subtitles, significant variations in translation can be seen in the linguistic transfer of swear words in subtitles. The variations in transference cannot be clarified purely by the usual functional restrictions that subtitlers encounter, such as spatial and temporal constraints. Regarding constraints, they may be human, technical, or linguistic (Gottlieb, 1992).

The concept of subtitling swear words is very interesting. The researcher wishes to conduct research on subtitling and swear words. In this article, the researcher will use Gottlieb's (1992) theory of subtitling strategy as a tool to analyze what strategies that the subtitlers employed when they are translating the swear words in Deadpool One and Deadpool Two films. This famous comedic superhero film starred by Ryan Reynold is chosen because these two films contain many swear words mentioned in the entire film and also because of the incredible level of success these two Marvel Studios films got despite being R-rated.

Several studies (Han \& Wang, 2014; Hawel, 2019; Nguyen, 2015; Sadewa \& Nugroho, 2015; Simanjuntak, 2016; Slamia, 2020; Wibowo, 2017) has researched strategies in translating swear words. All of the studies mentioned above are examples of the high interests that many researchers have regarding subtitling and swear words. The first study is made by Han \& Wang (2014). Their article analyzes the subtitling of English swear words into Chinese in the television series. The results of their study are in both languages. The total prevalence of swear words, as well as the number of semantic categories and functions represented by swear words, indicate a difference. Besides, despite the restrictions imposed by the medium, the subtitles act as an efficient bridge between the original program and the intended audience.

The second study is made by Hawel (2019) their article analyzes the strategies of subtitling swear words in a film. The results of their study are that the subtitler has followed six strategies which are deletion, softening, register shift, change in the semantic field, addition, and literal translation. The third study is made by Slamia (2020) whose study seeks to raise awareness about the particular use of certain strategies and to illustrate the subsequent changes, omissions, and errors in the target language. The study also looks at how taboo words, such as lexemes and/or phrases about death, sex, swearing, religion, and calling names, are translated. The fourth study is made by Nguyen (2015), their study is about the linguistic transfer of taboo language in a film from English to Dutch. According to their study, it is found that 


\section{Rohmawati}

there is much loss in the transfer of swear words into Dutch and that the translator's efforts to compensate for the loss are insufficient.

The fifth study is made by Sadewa \& Nugroho (2015), they talk about the translation strategies of swear words found in film subtitle from English into Indonesian. They found that the subtitler employed ten strategies when transferring the swear words into Indonesian. The sixth study is made by Simanjuntak (2016). The research is also about the subtitling strategies of swear words. However, He found that the subtitler only employed six strategies. The seventh and the last study is made by Wibowo (2017), who talks about the subtitling strategies of African and American slang expression.

The seven studies mentioned above are all related to this research. The first three studies only focus on the use of swear words (Han \& Wang, 2014; Hawel, 2019; Slamia, 2020). While the fourth is mainly about taboo language rather than swear words (Nguyen, 2015). The last three studies are quite close to this research because they also use subtitling strategy as their tool of analysis (Sadewa \& Nugroho, 2015; Simanjuntak, 2016; Wibowo, 2017), however, in this article, the researcher will not only analyze the strategies that the subtitlers employed when they are making subtitles for swear words but will also discuss the differences that are found between the English swear words found in the original subtitles and the Indonesian subtitles. Moreover, the researcher will also show the results of the research based on the Indonesian culture customs about swear words.

This research is very interesting to do because the more advanced the audiovisual translation in Indonesia, there will be more new languages and more researches that are going to benefits many people. Thus, the research questions of this article are: 1) What subtitling strategies that the subtitler use when transferring the English swear words into Indonesian in Deadpool One Film? 2) What subtitling strategies that the subtitler use when they are subtitling the English swear words into Indonesian in Deadpool Two Film?

\section{LITERATURE REVIEW}

\subsection{Subtitling}

Subtitling is a form of audiovisual translation with its own set of guidelines, parameters, and requirements. It's a form of translation with time and space constraints that have a direct effect on the end product. Chaume (2013) stated that "subtitling is the process of displaying a written text (subtitles) in the target language on a screen where an original version of a movie is being shown so that the subtitles approximately conform to the dialogue of the screen actors." Gottlieb (2004) in his article added that subtitling could be defined as a "dia-semiotic translation of polysemiotic media (such as films, television series, video, and DVD) in the form of one or more lines of written text displayed on the screen in harmony with the original dialogue." from those two definitions of subtitling, it is clear that subtitle is in the 
form of written text that is added into the original film keeping all the original film discourse; it is synchronized with the speaker in the original film. Subtitling is a procedure that involves not only transferring the features of spoken dialogue into written form but also matching the translated dialogue to the audio and video in a specific time and space.

Being a subtitler is not an easy job, a good subtitler need to be an excellent translator, they also need to have good hearing like a professional interpreter, have a good sense of judgment like an editor, and lastly have a great sense of aesthetic like a designer (Gottlieb, 2004). Gottlieb (1992) distinguishes between formal, or quantitative, and textual, or qualitative, subtitling restrictions; the former is imposed on the subtitles by the film's visual context, while the latter are space and time constraints. In reality, the visual context requires that the verbal component be restricted to what is not visible on screen to eliminate redundancy; nevertheless, space and time limitations can have a negative influence on efficiency of the subtitle as a product of translation.

Gottlieb (1992) explained that two forms of subtitling can be differentiated linguistically; the first form is intralingual subtitling, which is known as domestic subtitling that is usually used by people with disabilities in hearing. The second form is interlingual subtitling. It is a form of language translation where there is no change in the subtitles or translation in ST. However, the two elements are present in the subtitled version in perfect sync; the subtitler cross-over from translating the spoken foreign language dialog to showing a written domestic-language version on the screen. Gottlieb (1992) added that there are two types of subtitles, open and closed. Open subtitles, a kind of subtitles where the viewers cannot turn it off even if they do not need them. In contrast, closed subtitles can be optionally added in the original films.

\subsubsection{Subtitling Strategies}

Henrik Gottlieb (1992) is one of the most known experts in the field of audiovisual translation. in his article, Gottlieb proposes ten subtitling strategies which cover "expansion, paraphrase, transfer, imitation, transcription, dislocation, condensation, decimation, deletion, and resignation." The strategies will be further described below:

Expansion strategy is employed when the source language dialogs need an additional explanation for the viewers to understand the subtitled words; as a result, the subtitled version in the target language becomes longer. A paraphrase strategy is employed when the translation in the target language is syntactically different from the source language, but the meaning is still retained to be comprehended by the viewers. A transfer strategy is employed when the expressions in the source language are translated completely and correctly in the target language. Imitation strategy is employed to translate proper nouns (for a specific person, place, or thing).

Indonesian Journal of EFL and Linguistics, 6(1), 2021 


\section{Rohmawati}

Transcription strategy is employed to translate unusual expressions or third language that are found in the source language. A dislocation strategy is employed to translate musical or visualized language-specific phenomena that are found in the source language. Condensation strategy is employed when the source language text is condensed in the target language while being as unobtrusive as possible; it is often used in normal speech. Decimation strategy is employed the content of the source language expressions is reduced significantly in the target language text; it is often used in fast speech. A deletion strategy is employed when there is a total deletion of the source language content in the target language text. The last strategy, the resignation strategy, is employed if the translator is unable to find a way to translating the source language subtitle, the meaning of the subtitle will be eventually lost.

\subsection{Swear Words}

There are many theories concerning swear words that are proposed by experts. Among them are (Allan \& Burridge, 2006; Jay, 2009; Ljung, 2011; McEnery, 2006). According to McEnery (2006) swear word is "a language that is considered to be not good; yet blasphemous, homophobic, racist, and sexist language may also cause more offense to someone." Based on his theory, swear words are considered as 'bad language' that will leave a negative impression on others. In line with the former definition, Allan \& Burridge (2010) stated that "swearing at someone or something is a form of provocation and deprecation, as well as the use of other dysphemisms." From their statement, it is clear that swear words are employed to insult or to speak offensively to other people or other objects. Jay (2010) added that "swearing is mainly used for emotional expression, which may take the form of epithets or insults aimed at others." Epithets are single words or phrases used to convey the speaker's annoyance, indignation, or surprise in an offensive manner. Jay (2010) also stated that "taboo words continue to exist because they can amplify emotional interactions in ways that non-taboo words cannot.

Ljung (2011) proposes four characteristics of swear words. The first characteristic is that the speaker should use taboo terms in their utterances. Second, the taboo terms in the utterances are used with non-literal meanings. Third, any swearing utterances are limited by extreme lexical, phrasal, and syntactic restrictions, suggesting that most swearing is formulaic language. Lastly, swearing is an emotive expression in which the speaker's thoughts and attitudes are expressed or seem to be reflected.

\subsubsection{The Typology of Swear Words}

Many experts proposed theories concerning the typology of swear words. One of the experts who put forward a theory about the typology of swear words is Ljung (2011). There are two typology categories which are functions and themes; "...functions are the purposes of the person who uses swear words, while themes are the various taboo areas that these constructions rely on." 
Ljung (2011) put forward seven functions of swear words, including "expletive interjections, oaths, curses, empathic denials, unfriendly suggestions, ritual insults, and name-calling." While there are two sub-group of themes (major and minor); "...the major theme covers the religious theme, the scatological theme, the sex organ theme, the sexual activities theme, and the mother theme; the minor theme covers the ancestor theme, the animal theme, the death theme, the disease theme, and the prostitution theme."

\subsection{Cultural Differences in Subtitling Swear Words}

Oxford Advanced Learner's Dictionary (Hornby et al., 2015) defined culture as a country's or group's customs and beliefs, art, way of life, and social organization. Subtitling swear words from English into Indonesian is not an easy task to do. The subtitlers will be bound to various constraints. One of those is cultural values that exist in Indonesia. The swear words culture in the United States and Indonesia is different. In Indonesian culture, swearing is considered a bad thing. Indonesia adheres to a culture of refinement and hospitality between humans. Therefore, the official distributors of American films in Indonesia always comply with the regulations in making subtitles based on cultural principles that exist in Indonesia.

\subsection{Synopsis Deadpool One \& Deadpool Two Films}

Deadpool One (Miller, 2016) tells a story about Wade Wilson, who is a former Special Forces operative that currently works as a mercenary in a hidden pub. When the wicked scientist Francis tortures, disfigures, and turns Wade into Deadpool, his world comes crashing down. Deadpool emerges from the rogue laboratory with enhanced healing abilities and a warped sense of humor.

While the story about Deadpool Two (Leitch, 2018) is about Deadpool that meets a young mutant named Russel who is wounded both physically and mentally by the orphanage to the point of madness. The film starts with Cable who comes from a future to hunt Russel, the killer who kills his entire family in the future. To stop Russel who runs amok with his new friend The Juggernaut to kill the headmaster of the orphanage Deadpool, Cable, Domino, Colossus, and others work together. In that situation, Deadpool sacrifices himself to save the young Russel from the destruction plot. Seeing Deadpool almost dying for his sake, Russel did not continue to kill the headmaster, thus, changing the future.

\section{RESEARCH METHODOLOGY}

In this research, the researcher uses a descriptive qualitative method to analyze the subtitling strategy of swear words in Deadpool One and Deadpool Two films. Dornyei (2007) stated that data collection procedures in qualitative research produce exclusively open-ended, non-numerical data, which is then analyzed primarily using non-statistical approaches. This research falls into the category of qualitative research because the data analysis will be served descriptively. This method is 


\section{Rohmawati}

employed by the researcher because the data used in this research are film subtitles, which are in the form of written words, specifically swear words. The researcher presents results, discussion, and analysis descriptively so that this research is categorized as descriptive research. The researcher will employ Gottlieb's (1992) ten subtitling strategies to analyze all of the swear words in both of the films. The swear words are going to be collected based on Ljung's (2011) characteristics of swear words.

\subsection{Source of the Data}

The researcher collects the data from the subtitles of Deadpool One and Deadpool Two films. The format for both of the films used in this study is Official DVD. Therefore, the subtitles that the researcher use for this research is official. Both of the films were distributed in Indonesia by PT Vision Interprima Pictures. Deadpool One DVD was published on April 19 ${ }^{\text {th }}, 2016$ with the censorship pass number: 2697/ DVD/ 21/ PA/ 01.2018/ 2016; the duration of the film is an hour and 48 minutes. While Deadpool Two DVD was published on August 14 ${ }^{\text {th }}, 2018$ with the censorship pass number: 660/ DVD/ 17/ PA/ 01.2019/2018; the duration of the film is an hour and 59 minutes.

From the source of the data, the researcher obtains 112 utterances and 166 utterances that contain swear words in Deadpool One and Deadpool Two as the sources of the data selected based on several phases of data selection. The data collected in this research are in the form of utterances that contain swear words that are collected by using Ljung's (2011) theory of swear words.

\subsection{Technique of Collecting Data}

Sugiyono (2010) stated that since the key goal of an analysis is to gather data sources, data collection techniques are the most strategic step in research. He went on to say that in a qualitative study, data is collected in a natural setting using primary sources, and the data collection techniques are primarily observation, interview, and documentation. Documentation is a method for gathering data from sources, such as event records, writings, pictures, and works of art (Sugiyono, 2010). Mujiono \& Ula (2020) stated there are many types of documents such as books, movie scripts, subtitles, novels, films, recordings, etc.

Since the source of the data in this research are in the form of swear words dialogue of Deadpool One and Deadpool Two films which are classified as a popular culture document, the data collection technique in this research is documentation. By employing the documentation method, the researcher dID several procedures of collecting data in this research which are:

Watching "Deadpool One" and "Deadpool Two" films. Next, transcribing the English and Indonesian subtitles from the DVDs. After that, collecting the swear 
words data from the two movie dialogues by putting them into tables using Ljung's (2011) theory of swear words.

\subsection{Procedure of Data Analysis}

Data analysis is the process of systematically identifying and arranging the film dialog script, notes, and other data to improve the researcher's knowledge of them and to allow the researcher to present what he or she has learned to others (Sugiyono, 2010). The steps to analyze the data in this research are as follows: eliminating utterances in the dialogues that do not have the characteristics of swear words without reducing important information needed, Presenting the data that has been collected to be analyzed descriptively using Gottlieb's theory of subtitling strategy, Lastly, concluding.

\section{FINDINGS}

In this section, the researcher presents the results and the analysis of the research that covers the subtitling strategies of swear words in Deadpool One and Deadpool Two films.

\subsection{Deadpool One}

In Deadpool One six subtitling strategies are used by the subtitler in subtitling the English swear words into Indonesian. The data obtained are presented in table number 1 below:

Table 1: Subtitling Strategies of Swear Words in Deadpool One Film

\begin{tabular}{|c|l|c|}
\hline No. & \multicolumn{1}{|c|}{ Subtitling Strategies } & Number of Data \\
\hline 1 & Paraphrase & 50 \\
\hline 2 & Deletion & 33 \\
\hline 3 & Condensation & 12 \\
\hline 4 & Decimation & 10 \\
\hline 5 & Transfer & 6 \\
\hline 6 & Expansion TOTAL & 1 \\
\hline \multicolumn{2}{|r|}{} \\
\hline
\end{tabular}

Based on the data shown in table number one it is clear that the most frequent strategies employed by the subtitler are paraphrase strategy with fifty data; followed by deletion strategy with thirty-three data; condensation strategy comes in third place with twelve data; while decimation strategy placed fourth with ten data; the two lowest strategies are transfer with six data and expansion with only one data. 


\subsection{Deadpool Two}

In Deadpool Two six subtitling strategies are used by the subtitler in subtitling the English swear words into Indonesian. The data obtained are presented in table number 2 below:

Table 2: Subtitling Strategies of Swear Words in Deadpool Two Film

\begin{tabular}{|c|l|c|}
\hline No. & \multicolumn{1}{|c|}{ Subtitling Strategies } & Number of Data \\
\hline 1 & Deletion & 65 \\
\hline 2 & Paraphrase & 47 \\
\hline 3 & Condensation & 20 \\
\hline 4 & Decimation & 19 \\
\hline 5 & Transfer & 12 \\
\hline 6 & Expansion TOTAL & 3 \\
\hline \multicolumn{2}{|c|}{} & 166 \\
\hline
\end{tabular}

Based on the data shown in table number two it is clear that the most frequent strategies employed by the subtitler are deletion strategy with sixty-five data; followed by paraphrase strategy with forty-seven data; condensation strategy comes in third place with twenty data; while decimation strategy placed fourth with nineteen data; the two lowest strategies are transfer with twelve data and expansion with three data.

\subsection{Data Analysis}

In this section, the researcher will provide the analysis of the data along with examples that are complemented with explanations in the form of description.

\subsubsection{Expansion}

An example of this strategy will be shown below:

Table 3: Example of Expansion Strategy (DP1: DATUM 98)

\begin{tabular}{|l|l|l|}
\hline Speaker & \multicolumn{1}{|c|}{ English } & \multicolumn{1}{c|}{ Indonesian } \\
\hline Vanessa & $\begin{array}{l}\text { Listen, we both know that } \\
\text { cancer is a shitshow. }\end{array}$ & $\begin{array}{l}\text { Dengar. Kita tahu kanker adalah } \\
\text { pertunjukan yang buruk. }\end{array}$ \\
\hline
\end{tabular}

Analysis:

The source text swear word "... shitshow ..." is translated into "... pertunjukan yang buruk ..." in the target text. In the Cambridge Dictionary (Walter, 2004), the word shitshow means a situation or event that is badly organized, unpleasant, and full of confusion. Since the word shitshow is an offensive word and has no exact equivalence in Indonesian, the subtitler translates it using the expansion strategy by adding an explanation in the form of an adjective in the target language which is buruk. The translation of this example is half equivalent because the expression "... 
pertunjukan yang buruk ..." is not a swear word expression in Indonesian, but it does deliver the literal meaning of the swear words to the target language.

\subsubsection{Paraphrase}

Table 4: Example of Paraphrase Strategy (DP1: DATUM 2)

\begin{tabular}{|l|l|l|}
\hline Speaker & \multicolumn{1}{|c|}{ English } & \multicolumn{1}{c|}{ Indonesian } \\
\hline AL & $\begin{array}{l}\text { Why such a douche this } \\
\text { morning? }\end{array}$ & $\begin{array}{l}\text { Kenapa kau menyebalkan pagi } \\
\text { ini? }\end{array}$ \\
\hline
\end{tabular}

Analysis:

The source text "... such a douche ..." is translated into "... kau menyebalkan ..." in the target text. In the Cambridge Dictionary (Walter, 2004), the word douche means an unpleasant or offensive person. The subtitler translates the source text expression using the paraphrase strategy because it cannot be reformed syntactically the same. Douche is listed as a noun in the Cambridge Dictionary. However, in the target text, the class of the word has been changed. The target text "... menyebalkan ..." is a verb. The message in the target text is not delivered well because the meaning is different from the original message in the source text.

\subsubsection{Transfer}

Table 5: Example of Transfer Strategy (DP2: DATUM 45)

\begin{tabular}{|l|l|c|}
\hline Speaker & \multicolumn{1}{|c|}{ English } & Indonesian \\
\hline AL & I'll burn your balls off! & Kubakar buah zakarmu! \\
\hline
\end{tabular}

Analysis:

The source text "... your balls ..." is translated into "... buah zakarmu ..." in the target text. In the Cambridge Dictionary (Walter, 2004), the word balls (offensive) refer to testicles. The subtitler translates the source text expression using the transfer strategy because balls (offensive) are equivalent to buah zakar in Indonesian. According to An Indonesian - English Dictionary (Echols \& Shadily, 2003), buah zakar is translated as testicles which is the synonym of balls.

\subsubsection{Condensation}

Table 6: Example of Condensation Strategy (DP1: DATUM 88)

\begin{tabular}{|l|l|l|}
\hline Speaker & \multicolumn{1}{|c|}{ English } & \multicolumn{1}{|c|}{ Indonesian } \\
\hline Wade & $\begin{array}{l}\text { (Narrating) Welcome to Sister } \\
\text { Margaret's. It's like a job fair for } \\
\text { mercenaries. Think of us like } \\
\text { really fucked up tooth fairies, } \\
\text { except we knock out the teeth and } \\
\text { take the cash. }\end{array}$ & $\begin{array}{l}\text { Selamat datang di Sister } \\
\text { Margaret's. Ini tempat mencari } \\
\text { kerja bagi tentara bayaran. Anggap } \\
\text { kami peri gigi yang gila tapi kami } \\
\text { memang meninju sampai gigi copot } \\
\text { dan dapat uang. }\end{array}$ \\
\hline
\end{tabular}

Indonesian Journal of EFL and Linguistics, 6(1), 2021 


\section{Rohmawati}

Analysis:

The source text "... fucked up ..." is a phrasal verb that means a psychological state of someone when they are not happy or mentally unstable (Walter, 2004) it is translated into "... gila ..." in the target text. The subtitler uses the condensation strategy by omitting the word "up" because it is the least important word, and the omission of it does not affect the meaning and the message in the target text. However, although the meaning is equivalent, the translation in the target text is not in a swear word expression which makes it only half equivalent.

\subsubsection{Decimation}

Table 7: Example of Decimation Strategy (DP1: DATUM 50)

\begin{tabular}{|l|l|l|}
\hline Speaker & \multicolumn{1}{|c|}{ English } & \multicolumn{1}{c|}{ Indonesian } \\
\hline Deadpool & $\begin{array}{l}\text { Fellas! Hey! Hey! you only work } \\
\text { for that shit-spackled muppet } \\
\text { fart! }\end{array}$ & $\begin{array}{l}\text { Kawan-kawan. Hei! Kalian hanya } \\
\text { bekerja untuk bedebah itu. }\end{array}$ \\
\hline
\end{tabular}

Analysis:

The source text "... shit-spackled muppet fart ..." is translated into "... bedebah ..." in the target text. The phrase "... shit-spackled muppet fart ..." means a stupid person whose brain is filled with a lot of bad things. Deadpool was saying those lines when he was in a fight with Francis's underlings. In this context, the subtitler omitted two words from the text, one of which is also important in the source text; "... shit-spackled ..." The subtitler translates "... shit-spackled muppet fart ..." into the word "... bedebah ..." which shows that the meaning is delivered well in the Indonesian target text. However, since "... bedebah ..." is not a swear word expression in Indonesian, it can be said that is the swear words transfer into the Indonesian target text is half equivalent.

\subsubsection{Deletion}

Table 8: Example of Deletion Strategy (DP2: DATUM 20)

\begin{tabular}{|l|c|c|}
\hline Speaker & English & Indonesian \\
\hline Deadpool & And nobody fucking realizes it. & Tak ada yang menyadarinya. \\
\hline
\end{tabular}

Analysis:

According to the Cambridge Dictionary (Walter, 2004), the word "... fucking ...." is employed to emphasize a statement, especially an angry one. Deadpool was reminiscing of his old memories of him and Vanessa when they were watching a song by Yentl; He got frustrated and then spoke those lines mentioned in the example above. However, this reference is not transferred in the target text as there 
is no translation of the adjective swear word 'fucking' that is used to emphasize the statement at all, which is why the subtitler uses deletion strategy.

\section{DISCUSSION}

The purpose of this research is to obtain data concerning the subtitling strategies of swear words that are found in the subtitles of Deadpool One and Deadpool Two films. Based on Gottlieb's (1992) theory of subtitling strategy, the subtitlers of Deadpool One and Deadpool Two employed six subtitling strategies respectively in both films. The subtitler in Deadpool one uses the paraphrase and deletion strategies the most, followed by condensation, decimation, and transfer, while the least used strategy is expansion. On the other hand, the subtitler in Deadpool Two uses deletion as the most used strategy with a whopping number of sixty-five times. The next strategies that the subtitler uses more are paraphrase, condensation, decimation, and transfer; the least used strategy is expansion. In the following paragraphs below, the researcher will compare the results in this research to more relevant studies:

Demirden \& Gedik (2020), in their article, are analyzing the swear words translation of a Turkish film into English. Their research results revealed that swear words are either entirely removed from the frame or have their meaning modified by being softened. In Ghaemi \& Benyamin's (2011) article, the results for subtitling swear words were also toned down by deletion. In this article, the researcher analyses two films; the removed swear words percentage in Demirden \& Gedik (2020) and Ghaemi \& Benyamin (2011) studies only amounted to $20 \%$ and $8,54 \%$, while in this research, the deletion amounts to 29\% in Deadpool One and 39\% in Deadpool Two.

In Khoshsaligheh \& Ameri's (2014) article, the result also revealed that the deletion and taboo to taboo strategies are the most frequent strategies employed among the four films that they are researching. Besides Khoshsaligheh \& Ameri's (2014) article, Chen (2004) also research the subtitling of swear words into his native language. The results of his study revealed that the swear words are often not translated at all, translated way too formally, or translated into euphemisms. In this research, the most frequent strategies that shown up are paraphrase and deletion. It is rare to find the transfer strategy in both Deadpool series subtitles; the subtitlers in both films also did not translate the swear words over formally in the Indonesian subtitle.

Sutrisno \& Ibnuz (2021) written an article about the translation strategies of the swear word 'fuck' in the subtitle from English into Indonesian. The results of their study showed that omission and mollification strategies are used to translate the English swear words with relatively normal words in the Indonesian subtitle.

Unlike the five relevant studies mentioned above, in an article written by Nugroho \& Asmarani (2019) the English swear words are translated as swear words too in the Indonesian subtitle; this happens because the translators are university students and the subtitle that they made is not distributed. Alsharhan (2020), in contrast, research 


\section{Rohmawati}

the subtitling of swear words from English into Arabic in five Netflix series. However, they only use the first seasons from all five shows as the data. The results show that unlike the other studies on subtitling of swear words, Netflix series tend to preserve the swear words in the target language mostly in the form of euphemisms. Their result is very different from this research because in this research, the subtitlers often toned down the swear words in the Indonesian language.

These seven relevant studies' results show that having the same social context as the target language society will lead to the same translation type and orientation. This is especially true if certain social ideals are protected by law. Five relevant studies proposed by (Chen, 2004; Demirden \& Gedik, 2020; Ghaemi \& Benyamin, 2011; Khoshsaligheh \& Ameri, 2014; Sutrisno \& Ibnuz, 2021) revealed that swear words are often omitted or translated into non-swearword in the target language subtitle. While, the last two articles are different because in their results of the research the source language swear words are translated as the equivalent swear words in the target language (Alsharhan, 2020; Nugroho \& Asmarani, 2019).

The results of the research in this article prove that both the subtitler for Deadpool One and Deadpool Two films are often employed paraphrase and deletion strategies to transfer the English swear words into Indonesian. The deletion and paraphrase of the context-related data could very well be influenced by the Indonesian social culture. The degree to which subtitles are compressed is determined by the socialcultural in the target language and linguistic context shown on the screen (Nguyen, 2015). Swear words in subtitles can be toned down or even deleted, depending on the subtitler's judgment or the policies of TV stations and movie theaters in a particular country (Scandura, 2004). This situation will surely be a problem in the Indonesian audiovisual translation industry because the translator will have no choice but to obey the government regulations. Scandura (2004) stated that there are four reasons for censorship in books, newspapers, radio, television programs, films, etc., which are politics, politically correctness, religion, and self-censorship. In swear words case, it is about religion, because Indonesia is the world's most populated Muslim state (Syarif, 2012). The act of swearing is blasphemous in Islam, so it is one of the reasons why there are many paraphrases and deletions in both of the films.

Besides, deletion and paraphrase in subtitling can result in information loss and lower subtitle quality. As a result, it seems that words and phrases with little or no significance are often omitted in the data, for example, the use of epithets to emphasize in English is not translated in Indonesian.

\section{CONCLUSION}

In conclusion, the cultural disparity between America and Indonesia is unavoidable when translating swear words. It is not always possible to translate swear words in English into their equivalent swear words in Indonesian. The target language, in this 
case, Indonesian, differs from English in terms of language characteristics. Besides that, in Indonesia, swear words are normally prohibited or banned to be shown to the general public by the government.

\section{REFERENCES}

Allan, K., \& Burridge, K. (2006). Forbidden words: Taboo and the censoring of language. Cambridge: Cambridge University Press.

Alsharhan, A. (2020). Netflix's No-censorship Policy in Subtitling Taboo Language from English into Arabic. Journal of Audiovisual Translation, 3(2), 7-28. https://doi.org/10.47476/jat.v3i2.2020.127

Amri, N. (2017). Penerjemahan Subtitle Film Django Unchained dari Bahasa Inggris ke Bahasa Indonesia. Jurnal KATA, $1(1), \quad 80$. https://doi.org/10.22216/jk.v1i1.1953

Amrullah, L. (2016). English Swear Words By Indonesian Learners. Journal of English Language Teaching and Linguistics, 1(1), 1. https://doi.org/10.21462/jeltl.v1i1.2

Chaume, F. (2013). The turn of audiovisual translation. Translation Spaces, 2, 105123. https://doi.org/10.1075/ts.2.06cha

Chen, C. (2004). On the Hong Kong Chinese subtitling of English swearwords. Meta, 49(1), 135-147. https://doi.org/10.7202/009029ar

Cintas, J. D. (2005). The ever-changing world of subtitling: some major developments. In Research on Translation for Subtitling in Spain and Italy. (pp. 17-26). The University of Alicante.

Cintas, J. D., \& Remael, A. (2014). Audiovisual Translation: Subtitling. In Audiovisual Translation: Subtitling. https://doi.org/10.4324/9781315759678

Demirden, İ., \& Gedik, T. (2020). Translation of Turkish Swear Words in Subtitling: GORA. International Journal of English Language \& Translation Studies, 8(1), 19-26. https://www.researchgate.net/publication/337919852

Dornyei, Z. (2007). Research Methods in Applied Linguistics. Oxford: Oxford University.

Echols, J. M., \& Shadily, H. (2003). Kamus Indonesia-Inggris (9th ed.). Jakarta: PT Gramedia Pustaka Utama.

Ghaemi, F., \& Benyamin, J. (2011). Strategies Used in the Translation of Interlingual Subtitling. Journal oF English Studies, 1(1), 39-49.

Gottlieb, H. (1992). Subtitling - A New University Discipline. In C. Dollerup \& A. Loddegaard (Eds.), Teaching Translation and Interpreting: Training, Talent, and Experience. John Benjamins Publishing Company. 
Rohmawati

Gottlieb, H. (2004). Subtitles and International Anglification. Nordic Journal of English Studies, 3(1), 219. https://doi.org/10.35360/njes.32

Han, C., \& Wang, K. (2014). Subtitling swearwords in reality tv series from English into Chinese: A corpus-based study of the family. Translation and Interpreting, 6(2), 1-17. https://doi.org/10.12807/ti.106202.2014.a01

Hawel, Z. H. (2019). Strategies of Subtitling Swear words in The Wolf of Wall Street Movie. Lark Journal for Philosophy, Linguistics and Social Sciences, 3(34), 423-432. https://doi.org/10.31185/lark.vol3.iss34.1101

Hornby, A. S., Deuter, M., Bradbury, J., Turnbull, J., Hey, L., \& Holloway, S. (2015). Oxford Advanced Learner's Dictionary of Current English. Oxford: Oxford University Press.

Jay, T. (2009). The Utility and Ubiquity of Taboo Words. Perspectives on Psychological Science. Interpersonal Pragmatic (Handbooks of Pragmatics 6), 4(2), 153-161. https://doi.org/10.1111\%2Fj.1745-6924.2009.01115.x

Kao, H. (2011). Coherence and Audience Reception in Subtitling (Issue March). Newcastle University.

Khoshsaligheh, M., \& Ameri, S. (2014). Translation of taboos in dubbed American crime movies into Persian. T\&I Review, 4(2), 25-50.

Leitch, D. (2018). Deadpool Two. Twentieth Century Fox.

Ljung, M. (2011). Swearing: A Cross-Cultural Linguistic Study. Palgrave Macmillan. https://doi.org/10.1057/9780230292376

McEnery, T. (2006). Swearing in English: Bad language, purity and power from 1586 to the present. Routledge.

Miller, T. (2016). Deadpool One. Twentieth Century Fox.

Mujiono, M., \& Ula, A. L. (2020). Sociopragmatics Analysis of Politeness Strategy of the Main Character's Dialogues of Tinker Bell in Secret of the Wings Movie. Indonesian Journal of EFL and Linguistics, 5(2), 229. https://doi.org/10.21462/ijefl.v5i2.270

Nguyen, T. M. K. (2015). A Comparative Case Study in DVD Subtitling: The Linguistic Transfer of Taboo Language in Reservoir Dogs from English into Dutch. July, 1-139.

Nugroho, R. A., \& Asmarani, R. (2019). Swearwords in Subtitling: A Case Study on Students' Translation Project. ASIAN TEFL Journal of Language Teaching and Applied Linguistics, 4(2), 141. https://doi.org/10.21462/asiantefl.v4i2.105

Sadewa, K., \& Nugroho, R. (2015). Swear Word Translation Strategies Analysis in Limitless Subtitle. 1-13. http://eprints.dinus.ac.id/17310/1/jurnal_16009.pdf

Sari, A. N., \& Zamzani, Z. (2020). An Analysis of Translation Strategies of 
Honorific Term in the Film "The Boss Baby." Indonesian Journal of EFL and Linguistics, 5(2), 355. https://doi.org/10.21462/ijefl.v5i2.289

Scandura, G. L. (2004). Sex, lies, and TV: Censorship and subtitling. Meta, 49(1), 125-134. https://doi.org/10.7202/009028ar

Simanjuntak, N. V. N. (2016). Subtitling Strategies in Real Steel Movie. Lite, 12(1), $17-36$.

Slamia, F. (2020). The Impact of Students' Proficiency in English on Science Courses in a Foundation Year Program. International Journal of Linguistics, Literature, and Translation (IJLLT), 3(11), 55-67. https://doi.org/10.32996/ijllt

Sugiyono. (2010). Metode Penelitian Kuantitatif, Kualitatif. dan R\&D. Bandung: Alfabeta.

Sutrisno, A., \& Ibnuz, N. (2021). Strategies of Subtitling the Word Fuck in The Wolf of Wall Street Movie. International Journal of English Language Studies (IJELS), 3(3), 36-43.

Syarif, M. I. (2012). Ahkam: Jurnal Ilmu Syariah. AHKAM: Jurnal Ilmu Syariah, 12(2), 109-116. http://journal.uinjkt.ac.id/index.php/ahkam/article/view/971

Walter, E. (2004). Cambridge Learner's Dictionary (2nd ed.). Cambridge: Cambridge University Press.

Wibowo, P. (2017). Subtitling Strategies of African-American Slang Expressions in Indonesian Subtitles Text Of Lee's Barbershop 3: The Next Cut. Quill, 6(7), 724-730. 